\title{
POLA AKTIVITAS FISIK ANAK USIA 6,0-12,9 TAHUN DI INDONESIA
}

\author{
Heryudarini Harahapp ${ }^{1,3}$, Sandjaja $^{2,3}$, Karlina Nur Cahyo ${ }^{3}$ \\ ${ }^{1}$ Pusat Teknologi Intervensi Kesehatan Masyarakat \\ 2Pusat Teknologi Terapan Kesehatan dan Epidemiologi Klinik \\ 3Persatuan Ahli Gizi Indonesia (PERSAGI) \\ yudariniharahap@yahoo.com
}

\begin{abstract}
ABSTRAK
Analisis ini bertujuan untuk memberikan gambaran tentang pola aktivitas fisik anak usia 6-12 tahun di Indonesia menurut jenis kelamin, tempat tinggal dan status sosial ekonomi dengan menggunakan data SEANUTS yang dikumpulkan pada tahun 2011. Aktivitas fisik dikumpulkan dengan menggunakan pedometer. Pedometer dipasang di pinggang anak selama dua hari berturut-turut. Nilai rata-rata dari jumlah langkah yang dihasilkan anak selama dua hari disebut sebagai aktivitas fisik yang dikategorikan menjadi 1) aktif $\geq 15.000$ dan 2) tidak aktif $<15.000$ langkah untuk anak laki-laki dan 1) aktif $\geq 12.000$ dan 2) tidak aktif $<12.000$ langkah untuk anak perempuan. Screen time adalah jumlah waktu anak berada di depan TV/komputer/play station per hari yang dikategorikan $<2$ jam atau $\geq 2$ jam per hari. Lebih dari setengah $(57,3 \%)$ anak Indonesia dikategorikan tidak aktif dan berada di depan TV/komputer/PS $\geq 2$ jam per hari $(55,2 \%)$. Proporsi anak yang tidak aktif lebih banyak pada anak laki-laki $(62,8 \%)$ dibanding anak perempuan $(52,3 \%)$, anak dari ibu dengan pendidikan tinggi $(61,0 \%)$ dibanding anak dari ibu dengan pendidikan rendah $(55,7 \%)$, dan anak dari ayah dengan pekerjaan tetap $(61,1 \%)$ dibanding anak dari ayah dengan pekerjaan tidak tetap (56,1\%). Proporsi screen time anak $\geq 2$ jam per hari lebih besar pada anak yang tinggal di perkotaan $(58,9 \%)$ dibanding pada anak yang tinggal di perdesaan $(51,6 \%)$, dan anak dari sosial ekonomi tinggi $(67,4 \%)$ lebih besar dari anak dari sosial ekonomi rendah $(40,7 \%)$.
\end{abstract}

Kata kunci: aktivitas fisik, pedometer, screen time, anak Indonesia

\section{ABSTRACT}

\section{PHYSICAL ACTIVITY PATTERN OF 6.0 - 12.9 YEARS OLD INDONESIAN CHILDREN}

The aimed of this study was to assess the physical activity patterns of $6-12$ years old Indonesian children according to sex, residence, and social economic status. The data of SEANUTS 2011 was analyzed. Physical activity (PA) was measured directly using pedometers for 2 consecutive days. Daily PA was defined as the average of number steps from two consecutive days, then PA was categorized into two groups those were active (average number of steps $\geq 15.000$ for boys or and $\geq 12.000$ for girls) and inactive (average number of steps $<15,000$ for boys or $<12000$ steps/day for girls). Screen time was the amount of time used by children interacted with the TV/computer/play station per day. Then it was categorized as $<2$ hours or $\geq 2$ hours per day. More than half $(57.3 \%)$ of Indonesian children was categorized as inactive and screen time $\geq 2$ hours per day $(55.2 \%)$. The proportion of inactive children was higher in boys $(62,8 \%)$ than girls $(52,3 \%)$, children from high educated mothers more active $(61,0 \%)$ than children from low educated mothers $(55,7 \%)$, and children who had father with fix job more active $(61,1 \%)$ than children who had father with temporary job. The screen time proportion $\geq 2$ hours per day was higher in urban children $(58,9 \%)$ than rural children $(51,6 \%)$, and children from high socio economic status (SES) $(64,6 \%)$ than from low SES $(40,7 \%)$.

Keywords: physical activity, pedometer, screen time, Indonesian children

\section{PENDAHULUAN}

Hasil Riskesdas 2013 menunjukkan prevalensi anak gemuk (> 2 SD) usia $6-12$ tahun pada tahun 2013 adalah 18.8 persen 1 . Prevalensi ini meningkat menjadi dua kali lipat dibandingkan dengan prevalensi tahun 2010 yaitu 9,2 persen $^{2}$. Salah satu faktor yang menyebabkan terjadinya peningkatan kegemukan pada anak adalah perubahan pola aktivitas fisik. Pola aktivitas fisik anak masa kini telah mengalami pergeseran dari zaman dulu yang lebih banyak bergerak menjadi lebih sedikit beraktivitas fisik. Sebagai contoh, dulu sering ditemui anak-anak bermain bola, petak umpet, atau lompat tali. Pada saat ini lebih 
banyak terlihat anak-anak berada di Warung Internet (Warnet) untuk bermain game online, atau pada keluarga yang mampu, anak-anak berada di depan komputer atau bermain dengan Smartphone atau Gadget canggih pada waktu luangnya. Prevalensi anak yang beraktivitas fisik tidak cukup di Brazil adalah 69,8 persen ${ }^{3}$. Di Indonesia, prevalensi anak yang tidak rutin berolah raga sebesar 39,4 persen 4 .

Jumlah energi yang dikeluarkan untuk aktivitas fisik seperti bermain bola, petak umpet atau lompat tali lebih besar jika dibanding dengan hanya duduk di depan komputer atau bermain dengan Smartphone. Oleh karena itu, anak yang lebih banyak duduk lebih berisiko untuk menjadi gemuk dibanding dengan anak yang aktif bergerak, dengan asupan makanan yang sama. Hasil analisis multivariat data Riskesdas tahun 2007 yang dilakukan oleh Sartika menunjukkan bahwa anak yang tidak rutin berolah raga berisiko untuk menjadi obesitas 1.4 kali $(95 \% \mathrm{Cl}: 1.287$ - 1.487) lebih tinggi dibanding anak yang rutin berolah raga ${ }^{4}$. Faktor yang berhubungan dengan obesitas adalah jenis kelamin, tingkat pendidikan, riwayat obesitas pada ayah, asupan protein dan kebiasaan merokok ${ }^{4}$.

Aktivitas fisik yang dilakukan secara teratur akan menurunkan risiko obesitas dan penyakit degeneratif lainnya seperti hipertensi, penyakit jantung, diabetes mellitus, osteoporosis, kanker dan sebagainya. Hasil penelitian yang dilakukan Boone ${ }^{5}$ menemukan bahwa aktivitas fisik pada anak usia SMP dan SMA penting untuk pembentukan kebiasaan seumur hidup serta untuk jangka pendek adalah pada pemantauan berat badan. Penelitian ini juga menyimpulkan bahwa mengurangi waktu anak didepan TV/komputer/PS dapat menjadi strategi untuk mengurangi kejadian obesitas, terutama pada wanita.

Pada saat ini di Indonesia hanya ada beberapa penelitian berbasis populasi tentang aktivitas fisik pada anak sekolah. Penelitian tersebut menggunakan instrumen yang berbeda dengan penelitian SEANUTS. Analisis ini bertujuan untuk memberikan gambaran tentang pola aktivitas fisik dan screen time anak usia 612 tahun di Indonesia menurut gender, tempat tinggal dan status sosial ekonomi.

\section{METODE PENELITIAN}

Jumlah sampel anak usia 6,0-12,9 tahun adalah 3.787 orang, data anak dengan aktivitas fisik adalah 2.601 orang, dan data anak dengan screen time adalah 2.558 orang.

Aktivitas fisik dikumpulkan dengan menggunakan pedometer dengan merek Digiwalker pada anak yang berusia 6.0 - 12.9 tahun. Cara penggunaan pedometer adalah sebagai berikut 1) pedometer di set ke angka 0 dan set hari sebelum dipasang, 2) pedometer dipasang pada ikat pinggang/celana/rok dan diletakkan di kiri atau kanan pinggang, kemudian dipasang tali pada ikat pinggang anak untuk mencegah kehilangan pedometer, 3) pedometer dilepaskan jika melakukan kegiatan yang menyebabkan pedometer menjadi basah, 4) setelah dipasang selama $2 \times 24$ jam, data jumlah langkah dicatat di dalam kuesioner. Nilai rata-rata dari jumlah langkah yang dihasilkan anak selama dua hari disebut sebagai aktivitas fisik yang kemudian dikategorikan menjadi 1) aktif $\geq 15000$ dan 2) tidak aktif < 15000 langkah untuk anak laki-laki dan 1) aktif $\geq 12000$ dan 2) tidak aktif < 12000 langkah untuk anak perempuan $^{6,7}$.

Screen time (ST) adalah waktu yang digunakan oleh anak untuk menonton TV (TV), bermain komputer (PK), dan play station (PS). Data diperoleh dari wawancara dengan menggunakan kuesioner terstruktur tentang berapa lama anak melakukan kegiatan tersebut pada hari biasa dan pada hari minggu. Ratarata per hari dari ketiga kegiatan tersebut diperoleh dengan mengalikan 6 untuk hari biasa ditambah dengan kegiatan pada hari minggu, kemudian dibagi dengan 7 . Srceen time dikategorikan rendah jika $<2$ jam dan tinggi jika $\geq 2$ jam $^{8}$. Formula dari ST adalah sebagai berikut:

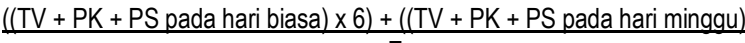

Data aktivitas fisik anak juga dikumpulkan dengan wawancara tentang aktivitas yang dilakukan anak selama $1 \times 24$ jam mulai bangun pagi sampai tidur malam, dan waktu yang digunakan untuk tiap aktivitas, namun data ini tidak dianalisis dalam tulisan ini. 
Data karakteristik anak dan orangtua diperoleh dari wawancara dengan kuesioner terstruktur. Data umur anak dikategorikan menjadi 6,0-8,9 tahun dan 9,0-12,9 tahun. Data tempat tinggal dikategorikan menjadi kota dan desa. Pendidikan orangtua dikategorikan menjadi SMA ke atas dan SMP kebawah. Pekerjaan ayah dikategorikan menjadi pekerjaan tetap dan pekerjaan tidak tetap, sedangkan pekerjaan ibu dikategorikan menjadi ibu rumah tangga, pekerjaan tetap dan pekerjaan tidak tetap. Data tingkat pendapatan didekati dari tingkat kepemilikan barang berharga keluarga yang dikompositkan menjadi status sosial ekonomi yang dikategorikan ke dalam 5 kelompok kuintil.

Analisis data menggunakan uji Chi-Square, Mean Whitney dan Kruskal Wallis.

\section{HASIL}

Jumlah sampel yang dianalisis untuk aktivitas fisik setelah dilakukan pembobotan adalah 2.601, dan screen time adalah 2.558 orang.

Tabel 1

Karakteristik sampel

\begin{tabular}{|c|c|c|c|c|}
\hline \multirow{2}{*}{ Karakteristik } & \multicolumn{2}{|c|}{ Aktivitas fisik } & \multicolumn{2}{|c|}{ Screen time } \\
\hline & $n$ & $\%$ & $\mathrm{n}$ & $\%$ \\
\hline \multicolumn{5}{|l|}{ Jenis Kelamin } \\
\hline Laki-laki & 1315 & 50,6 & 1298 & 50,7 \\
\hline Perempuan & 1286 & 49,4 & 1260 & 49,4 \\
\hline Total & 2601 & 100,0 & 2558 & 100,0 \\
\hline \multicolumn{5}{|l|}{ Umur (tahun) } \\
\hline $6.0-8.9$ & 1446 & 55,6 & 1424 & 55,7 \\
\hline $9.0-12.9$ & 1155 & 44,4 & 1134 & 44,3 \\
\hline Total & 2601 & 100,0 & 2558 & 100,0 \\
\hline \multicolumn{5}{|l|}{ Tempat tinggal } \\
\hline Kota & 1270 & 48,8 & 1257 & 49,1 \\
\hline Desa & 1331 & 51,2 & 1301 & 50,9 \\
\hline Total & 2601 & 100,0 & 2558 & 100,0 \\
\hline \multicolumn{5}{|l|}{ Pendidikan Ayah ${ }^{1}$} \\
\hline SMA keatas & 974 & 37,7 & 971 & 38,2 \\
\hline SMP kebawah & 1607 & 62,3 & 1568 & 61,8 \\
\hline Total & 2581 & 100,0 & 2539 & 100,0 \\
\hline \multicolumn{5}{|l|}{ Pendidikan Ibu ${ }^{1}$} \\
\hline SMA keatas & 780 & 30,1 & 768 & 30,1 \\
\hline SMP kebawah & 1815 & 69,9 & 1785 & 69,9 \\
\hline Total & 2595 & 100,0 & 2553 & 100,0 \\
\hline \multicolumn{5}{|l|}{ Pekerjaan Ayah ${ }^{1}$} \\
\hline Pekerjaan tetap & 522 & 20,3 & 522 & 20,7 \\
\hline Pekerjaan tidak tetap & 2045 & 79,7 & 2004 & 79,3 \\
\hline Total & 2567 & 100,0 & 2526 & 100,0 \\
\hline \multicolumn{5}{|l|}{ Pekerjaan lbu1 } \\
\hline lbu rumah tangga & 1481 & 57,3 & 1458 & 57,4 \\
\hline Pekerjaan tetap & 218 & 8,4 & 218 & 8,6 \\
\hline Pekerjaan tidak tetap & 885 & 34,3 & 866 & 34,1 \\
\hline Total & 2584 & 100,0 & 2542 & 100,0 \\
\hline \multicolumn{5}{|l|}{ Tingkat pendapatan ${ }^{1}$} \\
\hline Kuintil I & 467 & 18,0 & 458 & 17,9 \\
\hline Kuintil II & 489 & 18,8 & 474 & 18,5 \\
\hline Kuintil III & 552 & 21,2 & 550 & 21,5 \\
\hline Kuintil IV & 508 & 19,5 & 494 & 19,3 \\
\hline Kuintil V & 584 & 22,5 & 582 & 22,8 \\
\hline Total & 2600 & 100,0 & 2558 & 100,0 \\
\hline
\end{tabular}


Pada variabel pendidikan dan pekerjaan orangtua terdapat missing value karena orangtua sampel sudah meninggal. Jumlah data screen time lebih sedikit dari data aktivitas fisik karena anak tidak dapat menjawab pertanyaan berapa lama waktu yang dibutuhkan berada di depan TV/komputer/PS. Pada Tabel 1 disajikan karakteristik sampel. Jumlah anak laki-laki hampir sama dengan jumlah anak perempuan. Proporsi anak yang tinggal di kota dan desa hampir sama. Proporsi orangtua dengan pendidikan SMP ke bawah lebih tinggi dibandingkan dengan orangtua dengan pendidikan SMA ke atas, demikian pula lebih banyak orangtua dengan pekerjaan tidak tetap dibandingkan dengan orangtua dengan pekerjaan tetap. Proporsi tingkat pendapatan orangtua berdasarkan kategori kuintil menunjukkan bahwa tidak terlalu besar perbedaan antara kuintil I dan II dengan kuintil III dan IV.

Rata-rata aktivitas fisik anak laki-laki lebih tinggi dibandingkan dengan anak perempuan $(p$ $<0,05$ ). Tidak terdapat perbedaan yang bermakna $(p>0,05)$ dari aktivitas fisik anak yang berusia 6,0-8,9 tahun dibandingkan dengan anak yang lebih tua yaitu 9,0-12,9 tahun, antara anak-anak yang tinggal di daerah perdesaan dengan anak-anak yang tinggal di perkotaan. Tidak ditemukan juga perbedaan aktivitas fisik anak menurut pendidikan dan pekerjaan orang ayah serta pekerjaan ibu, namun ditemukan perbedaan yang bermakna $(p<0,05)$ menurut pendidikan ibu dan tingkat pendapatan.

Tabel 2

Rerata Jumlah Langkah menurut Karakteristik Anak dan Sosial Ekonomi

\begin{tabular}{|c|c|c|c|c|}
\hline \multirow{2}{*}{ Karakteristik } & \multirow{2}{*}{$\mathrm{n}$} & \multicolumn{2}{|c|}{ Jumlah langkah } & \multirow{2}{*}{$p$} \\
\hline & & Rerata & SE & \\
\hline Jenis Kelamin & & & & $0,000^{2}$ \\
\hline Laki-laki & 1315 & 13378 & 149 & \\
\hline Perempuan & 1286 & 12007 & 128 & \\
\hline Umur (thn) & & & & $0,937^{2}$ \\
\hline $6.0-8.9$ & 1446 & 12731 & 131 & \\
\hline $9.0-12.9$ & 1155 & 12663 & 151 & \\
\hline Tempat tinggal & & & & $0,142^{2}$ \\
\hline Kota & 1270 & 12527 & 146 & \\
\hline Desa & 1331 & 12866 & 135 & \\
\hline Pendidikan Ayah ${ }^{1}$ & & & & $0,206^{2}$ \\
\hline SMA ke atas & 974 & 12591 & 162 & \\
\hline SMP ke bawah & 1607 & 12784 & 126 & \\
\hline Pendidikan Ibu ${ }^{1}$ & & & & $0,034^{2}$ \\
\hline SMA ke atas & 780 & 12304 & 163 & \\
\hline SMP ke bawah & 1815 & 12874 & 123 & \\
\hline Pekerjaan Ayah ${ }^{1}$ & & & & $0,067^{2}$ \\
\hline Pekerjaan tetap & 522 & 12457 & 227 & \\
\hline Pekerjaan tidak tetap & 2045 & 12806 & 110 & \\
\hline Pekerjaan Ibu ${ }^{1}$ & & & & $0,215^{3}$ \\
\hline Ibu rumah tangga & 1481 & 12890 & 131 & \\
\hline Pekerjaan tetap & 218 & 12470 & 320 & \\
\hline Pekerjaan tidak tetap & 885 & 12520 & 172 & \\
\hline Tingkat pendapatan ${ }^{1}$ & & & & $0,004^{3}$ \\
\hline Kuintil I & 467 & 13466 & 255 & \\
\hline Kuintil II & 489 & 12754 & 233 & \\
\hline Kuintil III & 552 & 12855 & 204 & \\
\hline Kuintil IV & 508 & 11958 & 212 & \\
\hline Kuintil V & 584 & 12543 & 207 & \\
\hline
\end{tabular}


Anak dari ibu yang tidak bekerja mempunyai aktivitas fisik lebih tinggi dibanding anak dari ibu yang bekerja, dan anak dari kuintil pendapatan paling rendah mempunyai aktivitas fisik paling tinggi dibanding dengan anak-anak dari kuintil lainnya (Tabel 2).

Ditemukan 1.490 anak dari total sampel atau lebih dari separuh $(57.3 \%)$ anak Indonesia dikategorikan sebagai tidak aktif. Pada Tabel 3 disajikan tingkat aktivitas fisik anak. Proporsi anak laki-laki yang tidak aktif lebih banyak dibandingkan dengan anak perempuan. Proporsi anak yang tidak aktif lebih besar dari ibu dengan pendidikan SMA ke atas atau pekerjaan ayah tetap dibandingkan pendidikan ibu tinggi atau pekerjaan ayah tidak tetap. Tidak terlihat perbedaan proporsi aktivitas anak berdasarkan umur, tempat tinggal, pendidikan ayah, pekerjaan ibu maupun tingkat pendapatan $(p>0,05)$.
Rata-rata screen time anak adalah $2.4 \pm$ 0.03 jam. Rata-rata waktu yang disarankan untuk berada di depan TV/komputer atau PS tidak lebih dalam 2 jam/hari ${ }^{8}$. Rata-rata Screen time anak laki-laki lebih tinggi dari anak perempuan, kelompok umur yang lebih muda lebih banyak dibanding anak dari kelompok umur yang lebih tua. Anak-anak yang tinggal di daerah perkotaan lebih tinggi berada di depan TV/komputer atau bermain PS dibanding dengan anak yang tinggal di perdesaan. Screen time anak dari orang tua yang berpendidikan tinggi lebih besar dibandingkan anak dari orang tua yang berpendidikan rendah. Anak dari ayah dengan pekerjaan tetap lebih banyak berada di depan TV/komputer atau bermain PS dibanding dengan anak dari ayah dengan pekerjaan tidak tetap. Semakin tinggi tingkat pendapatan semakin besar screen time dari anak.

Tabel 3

Tingkat Aktivitas Fisik menurut Karakteristik Anak dan Sosial Ekonomi Keluarga

\begin{tabular}{|c|c|c|c|c|}
\hline \multirow{2}{*}{ Karakteristik } & \multirow{2}{*}{$\mathrm{n}$} & \multicolumn{2}{|c|}{ Aktivitas fisik (\%) } & \multirow{2}{*}{$p$} \\
\hline & & Aktif & Tidak aktif & \\
\hline \multicolumn{5}{|l|}{ Jenis Kelamin } \\
\hline Laki-laki & 1315 & 37,8 & 62,8 & \multirow[t]{2}{*}{0,000} \\
\hline Perempuan & 1286 & 47,7 & 52,3 & \\
\hline \multicolumn{5}{|l|}{ Umur (thn) } \\
\hline $6.0-8.9$ & 1446 & 42,9 & 57,1 & \multirow[t]{2}{*}{0,755} \\
\hline $9.0-12.9$ & 1155 & 42,3 & 57,7 & \\
\hline \multicolumn{5}{|l|}{ Tempat tinggal } \\
\hline Kota & 1153 & 42,1 & 57,9 & \multirow[t]{2}{*}{0,568} \\
\hline Desa & 1208 & 43,2 & 56,8 & \\
\hline \multicolumn{5}{|l|}{ Pendidikan Ayah } \\
\hline SMA ke atas & 974 & 42,4 & 57,6 & \multirow[t]{2}{*}{0,766} \\
\hline SMP ke bawah & 1607 & 43,0 & 57,0 & \\
\hline \multicolumn{5}{|l|}{ Pendidikan Ibu } \\
\hline SMA ke atas & 780 & 39,0 & 61,0 & \multirow[t]{2}{*}{0,011} \\
\hline SMP ke bawah & 1816 & 44,3 & 55,7 & \\
\hline \multicolumn{5}{|l|}{ Pekerjaan Ayah } \\
\hline Pekerjaan tetap & 522 & 38,9 & 61,1 & \multirow[t]{3}{*}{0,039} \\
\hline Pekerjaan tidak tetap & 2046 & 43,9 & 56,1 & \\
\hline \multicolumn{4}{|l|}{ Pekerjaan Ibu } & \\
\hline Ibu rumah tangga & 1482 & 43,5 & 56,5 & \multirow[t]{3}{*}{0,579} \\
\hline Pekerjaan tetap & 218 & 39,9 & 60,1 & \\
\hline Pekerjaan tidak tetap & 885 & 42,5 & 57,5 & \\
\hline \multicolumn{5}{|l|}{ Tingkat pendapatan } \\
\hline Kuintil I & 467 & 45,4 & 54,6 & \multirow[t]{5}{*}{0,228} \\
\hline Kuintil II & 489 & 43,1 & 56,9 & \\
\hline Kuintil III & 552 & 44,7 & 55,3 & \\
\hline Kuintil IV & 508 & 39,0 & 61,0 & \\
\hline Kuintil V & 584 & 41,4 & 58,6 & \\
\hline
\end{tabular}


Tabel 4

Rerata Screen Time menurut Karakteristik Anak dan Sosial Ekonomi

\begin{tabular}{|c|c|c|c|c|}
\hline \multirow{2}{*}{ Karakteristik } & \multirow{2}{*}{$\mathrm{n}$} & \multicolumn{2}{|c|}{ Screen Time } & \multirow{2}{*}{$p$} \\
\hline & & Rerata & SE & \\
\hline Jenis Kelamin & & & & 0,0211 \\
\hline Laki-laki & 1298 & 2,4 & 0,04 & \\
\hline Perempuan & 1260 & 2,3 & 0,04 & \\
\hline Umur (thn) & & & & $0,000^{1}$ \\
\hline $6.0-8.9$ & 1424 & 2,4 & 0,04 & \\
\hline $9.0-12.9$ & 1134 & 2.3 & 0,04 & \\
\hline Tempat tinggal & & & & $0,000^{1}$ \\
\hline Kota & 1257 & 2,5 & 0,04 & \\
\hline Desa & 1301 & 2,3 & 0.04 & \\
\hline Pendidikan Ayah ${ }^{1}$ & & & & $0,000^{1}$ \\
\hline SMA keatas & 971 & 2,4 & 0,04 & \\
\hline SMP kebawah & 1568 & 2,3 & 0,03 & \\
\hline Pendidikan lbu ${ }^{1}$ & & & & $0,000^{1}$ \\
\hline SMA keatas & 768 & 2,6 & 0,05 & \\
\hline SMP kebawah & 1785 & 2,3 & 0,03 & \\
\hline Pekerjaan Ayah ${ }^{1}$ & & & & $0,022^{1}$ \\
\hline Pekerjaan tetap & 522 & 2,5 & 0,07 & \\
\hline Pekerjaan tidak tetap & 2004 & 2,3 & 0,04 & \\
\hline Pekerjaan Ibu ${ }^{1}$ & & & & $0,335^{2}$ \\
\hline Ibu rumah tangga & 1458 & 2,3 & 0,04 & \\
\hline Pekerjaan tetap & 218 & 2,4 & 0,10 & \\
\hline Pekerjaan tidak tetap & 866 & 2,3 & 0,05 & \\
\hline Tingkat pendapatan 1 & & & & $0,000^{2}$ \\
\hline Kuintil I & 458 & 2,0 & 0,07 & \\
\hline Kuintil II & 474 & 2,2 & 0,06 & \\
\hline Kuintil III & 550 & 2,4 & 0,06 & \\
\hline Kuintil IV & 494 & 2,4 & 0,06 & \\
\hline Kuintil V & 582 & 2,6 & 0,06 & \\
\hline
\end{tabular}

Ditemukan 1412 anak dari total sampel atau lebih dari setengah anak (55.2\%) duduk didepan layar TV, komputer atau PS $\geq 2$ jam sehari. Proporsi Screen time $\geq 2$ jam dari anak laki-laki yang berumur lebih muda lebih besar dibanding anak yang lebih tua, anak yang tinggal di perkotaan lebih besar dibanding anak yang tinggal di perdesaan, anak dari orang tua dengan pendidikan SMA keatas lebih besar dibanding anak dibanding orang tua dengan pendidikan SMP kebawah, anak dari ayah dengan pekerjaan tetap lebih besar dibanding anak dari ayah dengan pekerjaan tidak tetap, dan anak dari keluarga dengan kuintil pendapatan tinggi lebih besar dibanding anak dari keluarga dengan kuintil pendapatan rendah $(p<0.05)$.

\section{BAHASAN}

Penggunaan pedometer saat ini semakin populer sebagai alat untuk mengukur aktivitas fisik. Pedometer merupakan suatu alat sederhana, berukuran kecil, dan dapat digunakan dengan mudah oleh orang awam untuk mengukur kuantitas aktivitas fisik yang dikerjakan dalam satu waktu tertentu. Pengukuran aktivitas fisik dalam penelitian skala besar memerlukan metode yang rendah biaya, menyenangkan untuk subjek penelitian dan akurat. 
Tabel 5

Tingkat Screen Time menurut Karakteristik Anak dan Sosial Ekonomi

\begin{tabular}{|c|c|c|c|c|}
\hline \multirow{2}{*}{ Karakteristik } & \multirow{2}{*}{$\mathrm{n}$} & \multicolumn{2}{|c|}{ Screen time (\%) } & \multirow[b]{2}{*}{$\mathrm{p}$} \\
\hline & & $<2$ Jam & $\geq 2 \mathrm{Jam}$ & \\
\hline Jenis Kelamin & & & & 0,320 \\
\hline Laki-laki & 1298 & 43,8 & 56,2 & \\
\hline Perempuan & 1260 & 45,8 & 54,2 & \\
\hline Umur (thn) & & & & 0,000 \\
\hline $6.0-8.9$ & 1424 & 41,5 & 58,5 & \\
\hline $9.0-12.9$ & 1134 & 48,9 & 51,1 & \\
\hline Tempat tinggal & & & & 0,000 \\
\hline Kota & 1257 & 41,1 & 58,9 & \\
\hline Desa & 1301 & 48,4 & 51,6 & \\
\hline Pendidikan Ayah & & & & 0,000 \\
\hline SMA keatas & 971 & 40,1 & 59,9 & \\
\hline SMP kebawah & 1568 & 42,0 & 58,0 & \\
\hline Pendidikan lbu & & & & 0,000 \\
\hline SMA keatas & 768 & 37,9 & 62,1 & \\
\hline SMP kebawah & 1785 & 47,6 & 52,4 & \\
\hline Pekerjaan Ayah & & & & 0,000 \\
\hline Pekerjaan tetap & 522 & 35,4 & 64,6 & \\
\hline Pekerjaan tidak tetap & 2004 & 47,6 & 52,4 & \\
\hline Pekerjaan Ibu & & & & 0,280 \\
\hline Ibu rumah tangga & 1458 & 44,0 & 56,0 & \\
\hline Pekerjaan tetap & 218 & 42,2 & 57,8 & \\
\hline Pekerjaan tidak tetap & 866 & 46,9 & 53,1 & \\
\hline Tingkat pendapatan & & & & 0.000 \\
\hline Kuintil I & 458 & 59,3 & 40,7 & \\
\hline Kuintil II & 474 & 51,9 & 48,1 & \\
\hline Kuintil III & 550 & 42,9 & 57,1 & \\
\hline Kuintil IV & 494 & 40,9 & 59,1 & \\
\hline Kuintil V & 582 & 32,6 & 67,4 & \\
\hline
\end{tabular}

Wawancara aktivitas fisik dengan menggunakan kuesioner dapat digunakan untuk menentukan pola aktivitas orang dewasa, namun pada anak-anak yang belum memiliki kemampuan kognitif untuk mengingat rincian tentang pola aktivitas mereka sulit dilakukan. Menurut Sirar dan Pate ${ }^{9}$ pedometer mempunyai korelasi yang relatif tinggi dengan pengukuran konsumsi oksigen ( $r=0,62-0,93)$ atau dengan pengukuran langsung $(r=0,80-0,97)$. Pedometer lebih mungkin diadopsi untuk aplikasi klinis dan kesehatan masyarakat karena dapat menginterpretasikan berapa jumlah langkah dan selanjutnya dapat menggambarkan aktivitas fisik ${ }^{7}$.

Systematic review yang dilakukan oleh Tudor-Locke, et al ${ }^{7}$ menemukan bahwa pada remaja laki-laki jumlah langkah kaki per harinya lebih tinggi dibandingkan dengan remaja perempuan. Pada remaja laki-laki dalam seharinya dapat berjalan sekitar 12.000 16.000 langkah, sedangkan pada remaja perempuan dapat berjalan sekitar 10.000 14.000 langkah. Angka ini menjadi rekomendasi aktivitas fisik berjalan yang dianjurkan pada remaja dan anak-anak. Apabila anak-anak dan remaja tidak memenuhi rekomendasi angka tersebut, belum dapat dikatakan mereka memenuhi standar aktivitas fisik yang diharapkan, sehingga risiko terkena kegemukan atau gangguan-gangguan lain menjadi lebih tinggi. Remaja yang overweight atau obesitas, ternyata memiliki jumlah langkah yang lebih sedikit setiap harinya dibandingkan pada remaja dengan angka BMI normal. Hal tersebut menunjukkan bahwa kegemukan cenderung 
lebih banyak terjadi pada remaja yang tidak aktif secara fisik dibanding pada remaja yang aktifí ${ }^{10}$.

Prevalensi anak Indonesia yang tidak aktif adalah 57,3 persen. Hasil penelitian ini menunjukkan bahwa proporsi anak laki-laki yang tidak aktif lebih besar dibanding anak perempuan $(p<0.05)$. Hal ini karena screen time anak laki-laki juga lebih tinggi dibandingkan dengan anak perempuan. Berbagai hasil penelitian menunjukkan bahwa anak-anak yang tinggal di daerah perdesaan lebih aktif, dengan alasan ruang tempat untuk bermain anak di desa lebih banyak dan luas dibanding anak yang tinggal di daerah perkotaan ${ }^{11}{ }^{12}$. Pada penelitian ini tidak ditemukan ada perbedaan tingkat aktivitas fisik anak menurut tempat tinggal. Penelitian yang dilakukan oleh Hodgkin et al13 di New Zealand menunjukkan hal yang sama dengan hasil penelitian ini. Hal ini diduga karena tersedianya alat transportasi untuk pergi atau pulang sekolah.

Prevalensi screen time anak $\geq 2$ jam perhari adalah 55,2 persen. Penelitian yang dilakukan di Kanada menunjukkan bahwa 82 persen anak perempuan dan 86 persen anak laki-laki berada di depan TV dan komputer $\geq 2$ jam perhari ${ }^{14}$, di Amerika 44 persen anak menonton TV $\geq 2$ jam per hari ${ }^{15}$. Anak-anak yang tinggal di perkotaan mempunyai screen time lebih tinggi dibanding yang tinggal di perdesaan. Hasil yang sama juga ditemukan pada penelitian Hodgkin et al ${ }^{13}$. Di Indonesia hal ini diduga karena di daerah perkotaan fasilitas untuk berada di depan TV/Komputer/PS lebih banyak tersedia di daerah perkotaan dibanding di pedesaan.

Anak-anak dari SES rendah di Amerika menunjukkan kecenderungan tingkat aktivitas fisik lebih rendah dan menghabiskan lebih banyak waktu dalam perilaku sedentary (kurang gerak) dibandingkan anak dari keluarga dengan SES tinggi. Anak-anak dari SES rendah lebih banyak menghabiskan waktu untuk menonton TV dibanding anak dari SES tinggi ${ }^{16}$. Menurut Kantomaa ${ }^{17}$ anak-anak dari rumah tangga dengan pendapatan tahunan lebih tinggi lebih banyak terlibat dalam klub olahraga, sehingga anak menjadi lebih aktif. Hasil penelitian terdahulu dilakukan di negara-negara maju berbeda keadaannya dengan dengan keadaan di Indonesia. Hasil penelitian ini menemukan bahwa anak dari kuintil pendapatan I paling aktif dibanding kuintil pendapatan lainnya, anak dari ayah yang bekerja tidak tetap lebih tinggi aktivitasnya dibanding anak dari ayah dengan pekerjaan tetap. Hal ini karena di negaranegara berkembang, anak-anak dari SES rendah membantu orang tua untuk mencari tambahan penghasilan atau membantu orang tua dalam mengerjakan pekerjaan rumah tangga.

Proporsi screen time dari anak dari pendidikan orang tua (ayah dan ibu) SMA keatas lebih besar dibanding anak dari pendidikan orang tua SMP kebawah $(p<0.05)$. Orang tua yang berpendidikan lebih tinggi dapat menyediakan fasilitas yang mendukung untuk proses belajar yaitu komputer. Selain itu orang tua yang berpendidikan tinggi diduga mempunyai pendapatan yang juga tinggi sehingga dapat menyediakan TV, PS atau komputer di rumah.

Aktivitas fisik dan perilaku sedentary saat ini menjadi fokus utama dalam penelitian, intervensi, dan kebijakan untuk mengatasi obesitas. Perilaku sedentary, seperti menonton TV dan bermain komputer dapat mempengaruhi keseimbangan energi melalui penurunan aktivitas fisik, meningkatkan asupan energi, atau mengurangi tingkat metabolisme. Hasil dari studi prospektif observasional menunjukkan bahwa peningkatan aktivitas fisik dan penurunan perilaku sedentary dapat mencegah kenaikan berat badan dan kegemukan pada anak dan remaja ${ }^{18}$. Kegemukan atau obesitas dapat meningkatkan risiko terjadinya sindrom metabolik. Pada anak yang kegemukan dan obesitas, jika terjadi kenaikan IMT sebesar setengah unit akan berisiko metabolik sindrom atau anak yang kegemukan dan gemuk berisiko 1,55 kali $(\mathrm{OR}=1,55,95 \% \mathrm{Cl}: 1,16-2,08)$ menderita metabolik sindrom dibanding anak yang normal' ${ }^{19}$. Penelitian lain menunjukkan bahwa anak yang tidak memenuhi rekomendasi aktivitas fisik (13.000 langkah untuk anak lakilaki atau 11.000 langkah untuk perempuan) atau screen time ( $\geq 2$ jam per hari) berisiko 3 4 kali untuk menjadi gemuk dibanding anak yang memenuhi kedua rekomendasi ini20.

\section{SIMPULAN DAN SARAN}

\section{Simpulan}

Proporsi anak Indonesia yang tidak aktif adalah 57,3 persen dan proporsi anak berada di 
depan TV/komputer/PS (screen time) dua jam atau lebih per hari adalah 55,2 persen.

Proporsi anak laki-laki (62,8\%) lebih banyak yang tidak aktif dibanding anak perempuan $(52,3 \%)$, anak dari ibu dengan pendidikan SMA keatas $(61,0 \%)$ lebih banyak tidak aktif dibanding anak dari ibu dengan pendidikan SMP kebawah $(55,7 \%)$, dan anak dari ayah dengan pekerjaan tetap $(61,1 \%)$ lebih banyak tidak aktif dibanding anak dari ayah dengan pekerjaan tidak tetap $(56,1 \%)$.

Proporsi anak berada di depan TV/komputer/PS dua jam atau lebih per hari lebih besar pada anak dari kelompok umur yang lebih muda $(58,5 \%)$ atau tinggal di perkotaan $(58,9 \%)$ dibanding pada anak dari kelompok umur lebih tua $(51,1 \%)$ atau tinggal di perdesaan $(51,6 \%)$, anak-anak dari ayah dengan pendidikan SMA keatas $(59,9 \%)$ lebih besar dibanding anak dari anak dari ayah dengan pendidikan SMP kebawah $(58,0 \%)$, anak dari ayah dengan pekerjaan tetap $(64,6 \%)$ lebih besar dibanding anak dari ayah dengan pekerjaan tidak tetap $(52,4 \%)$, dan anak dari sosial ekonomi tinggi $(67,4 \%)$ lebih besar dari anak dari sosial ekonomi rendah $(40,7 \%)$.

\section{Saran}

Hasil penelitian ini menunjukkan lebih dari separuh anak Indonesia tidak aktif dan berada di depan TV/komputer/PS dua jam atau lebih per hari. Aktivitas fisik yang rendah dan prilaku kurang gerak akan meningkatkan risiko terjadinya obesitas, yang selanjutnya berisiko pada timbulnya penyakit degeneratif pada usia dewasa. Berdasarkan fakta ini perlu dilakukan suatu program intervensi untuk membuat anak menjadi lebih aktif dan bergerak. Program intervensi dilakukan pada populasi yang berbeda misalnya antara anak-anak yang tinggal di perkotaan dan perdesaan, atau anakanak dari sosial ekonomi rendah dan tinggi. Diperlukan penelitian lebih lanjut tentang strategi pencegahan dan promosi yang terpadu untuk prilaku kurang gerak.

\section{UCAPAN TERIMA KASIH}

Terima kasih kami sampaikan kepada FrieslandCampina, Frisian Flag Indonesia yang telah mendukung penelitian ini, DPP Persagi Pusat, dan berbagai pihak yang telah berpartisipasi dalam Studi SEANUTS.

\section{RUJUKAN}

1. Departemen Kesehatan, Badan Penelitian dan Pengembangan Kesehatan. Riset Kesehatan Dasar 2013. Laporan Nasional. Jakarta: Departemen Kesehatan, 2013.

2. Departemen Kesehatan, Badan Penelitian dan Pengembangan Kesehatan. Riset Kesehatan Dasar 2010. Laporan Nasional. Jakarta: Departemen Kesehatan, 2011.

3. Bastos JP, Araújo CLP, Hallal PC. Prevalence of Insufficient Physical Activity and Associated Factors in Brazilian Adolescents. Journal of Physical Activity and Health.2008; 5:777-794.

4. Sartika RAD. Faktor risiko obesitas pada anak 5 - 15 tahun di Indonesia. Makara, Kesehatan.2011; 15 (1): 37 -43.

5. Boone JE, Gordon-Larsen P, Adair LS, and Popkin BM. Screen time and physical activity during adolescence: longitudinal effects on obesity in young adulthood. International Journal of Behavioral Nutrition and Physical Activity. 2007:4:26

6. Tudor-Locke, Pangrazi C, Robert P. BMlreferenced standards for recommended pedometer-determined steps/day in children. Preventive Medicine. 2004: 38(6), 857-864.

7. Tudor-Locke C, Craig CL, Beets MW, Belton S, Cardon GM, Duncan S, Hatano Y, Lubans DR, Olds TS, Raustorp A, Rowe DA, Spence JC, Tanaka S and Blair SN. How Many Steps/Day are Enough? for Children and Adolescents. International Journal of Behavioral Nutrition and Physical Activity. 2011; (8) 78.

8. American Academy of Pediatrics. Children, adolescents, and television. Pediatrics 2001;107:423-6.

9. Sirard JR and Pate RR. Physical activity assessment in children and adolescent. Sports Med. 2001:31 (6), 439 - 454.

10. McCormack GR, Rutherford J, Giles-Corti $B$, Tudor-Locke C \& Bull F. BMI-referenced cut-points for recommended daily pedometer-determined steps in Australian cehildren and adolescent. Research Quartely for Exercise and Sport. 2011; 82 (2):162 - 167

11. Potvin L, Gauvin L, Nguyen NM. Prevalence of stages of change for physical activity in rural, suburban and inner-city 
communities. Journal of Community Health 1997; 22(1): 1-13.

12. Loucaides CA, Chedzoy SM, Bennett N. Differences in physical activity levels between urban and rural school children in Cyprus. Health Education Research 2004; 19(2): 138-147.

13. Hodgkin E, Hamlin MJ, Ross JJ, Peters F. Obesity, energy intake and physical activity in rural and urban New Zealand children. Rural and Remote Health. 2010; 10: 1336. Available from: http://www.rrh.org.au. Download 14 Februari 2014

14. Mark AE, Boyce WF, Janssen I. Television viewing, computer use and total screen time in Canadian youth. Paediatr Child Health. 2006: Vol 11 No 9, $595-599$.

15. Crespo CJ, Smit E, Troiano RP, Bartlett SJ, Macera CA, Andersen RE. Television watching, energy intake and obesity in US children. Arch Pediatr Adolesc Med. 2001:155, 360-365.

16. Drenowatz $C$, Eisenmann JC, Pfeiffer $K A$, Welk G, Heelan K, GentileD and Walsh D. Influence of socio-economic status on habitual physical activity and sedentary behavior in 8- to 11-year old children. BMC Public Health. 2010; 10:214. http://www.biomedcentral.com/14712458/10/214
17. Kantomaa MT, Tammelin TH, Näyhä S, Taanila AM: Adolescents' physical activity in relation to family income and parents' education. Prev Med. 2007; 44:410-415.

18. Must A, Tybor DJ. Physical activity and sedentary behavior: a review of longitudinal studies of weight and adiposity in youth. Abstract.Int J Obes (Lond) 2005, 29 Suppl 2:S84-96.

19. Weiss R, Dziura J, Burgert TS, Tamborlane WV, Taksali SE, Yeckel CW,Allen A, Lopes M, Savoye M, Morrison J, Sherwin RS, and Caprio S.Obesity and the Metabolic Syndrome in Children and Adolescents. N Engl J Med 2004;350:2362-74.

20. Laurson KR, Eisenmann JC, Welk GJ, Wickel EE, Gentile DA, and Walsh DA. Combined Influence of Physical Activity and Screen Time Recommendations on Childhood Overweight. J Pediatr. 2008;153:209-14. 